\title{
Imported technology and manufacturing employment in Ethiopia
}

\author{
Getinet Haile $^{1,4} \cdot$ Ilina Srour ${ }^{2} \cdot$ Marco Vivarelli $^{2,3,4}$
}

Received: 28 September 2015/Revised: 26 January 2016/Accepted: 24 March 2016/ Published online: 17 May 2016

(C) The Author(s) 2016. This article is published with open access at Springerlink.com

\begin{abstract}
There is a dearth of research on the impact of technological change over employment in least developed countries (LDCs) embarking on globalization and consequent international technological transfer. Using a panel of 1940 Ethiopian firms over the period 1996-2004 and deploying GMM-SYS estimates, this paper aims to establish the role played by trade, FDI and technology in affecting employment and skills. The results obtained lend support to a labour-augmenting effect. Moreover, the implemented two-equation dynamic framework provides evidence of a skill-bias specific to those enterprises with higher share of foreign ownership and located in the vicinity of the capital city.
\end{abstract}

Keywords Employment · Skills · Globalization · FDI · Trade · Technological change $\cdot$ Ethiopia

JEL Classifications $\mathrm{J} 21 \cdot \mathrm{O} 33 \cdot \mathrm{J} 24$

Ilina would like to thank the University of Nottingham for the academic and institutional support she received during her visit in summer 2013, which made possible undertaking some of the empirical analysis in this paper. The usual disclaimer applies.

$\checkmark$ Getinet Haile

getinet.haile@nottingham.ac.uk

1 University of Nottingham, Jubilee Campus, Wollaton Road, NG8 1BB Nottingham, UK

2 Università Cattolica del Sacro Cuore, Milano, Piacenza, Italy

3 SPRU, University of Sussex, Brighton, UK

4 Institute for the Study of Labour (IZA), Bonn, Germany 


\section{Introduction}

Economic theory acknowledges the key role played by technology in stimulating economic progress and development. However, the consequences of technological change and its direct and indirect impacts on the dynamics of labour markets remain a matter of debate. A large body of literature has studied the effect of technological progress on employment in developed countries, the leaders in technological innovation. Developing countries, viewed as followers in terms of technology and innovation, have also had a significant share of this literature, particularly on the effect of technology transfers on employment and skill distribution. However, the impact of technology on labour is much less well-known in the least developed countries (LDCs) that have liberalized their trade and have opened their economies to direct technological imports or embodied technological transfers.

Technological progress is very slow in LDCs, and most of them rank poorly on various international technology and innovation indices such as the Technological Achievement Index, and the Innovation Capability Index (UNCTAD 2007). However, as many of these countries have adopted trade liberalisation policies over the past few decades, they face a major challenge enhancing the knowledge and technology intensity of their economies to be able to compete in national and international markets. In a study on technology transfer and skill accumulation in LDCs, Mayer (2000) shows that, overall, technological integration of LDCs has increased, though the disparities between the different countries are quite significant. However, he argues that LDCs need human capital to better exploit their improved access to technology, as well as instituting adequate economic policies and supporting institutions that promote modern technology that LDCs can import.

Within this context, the present paper aims to study the effect of imported technology on manufacturing employment in Ethiopia over the period 1996-2004. The paper also investigates the existence of skill biased technological change. Ethiopia is one of the least developed countries in the world today. It adopted a national structural adjustment program in 1991 and moved away from an importsubstitution strategy adopting a relatively open trade system. Therefore, it provides a suitable setting for studying the effect of imported technology on employment and to test the hypothesis of imported technology and skill bias.

The paper has three main novelties vis-à-vis previous literature in the area. First, it is one of the few papers studying the impact of trade openness and technology transfer in an LDC context. Second to our knowledge-it is the first paper investigating these issues in the Ethiopian context. Third, it deploys an empirical strategy, which jointly assess the quantitative and qualitative (both absolute and relative skill bias, see Sect. 5) impact of globalization and technology transfer.

The rest of the paper is organized into six sections. Section 2 discusses the relevant literature. Section 3 sheds light on the process of trade liberalization in Ethiopia and presents some descriptive evidence on the manufacturing sector and its employment evolution. Section 4 presents the data used in the empirical analysis. 
Section 5 specifies the empirical model and defines the variables used in the regression analysis. Section 6 presents and discusses the results obtained before the final section concludes the paper with a summary of the main findings and their implications.

\section{The literature}

Technological change allows producing the same level of output with lower level of inputs, namely capital and labour. The literature on the complementarity between technological change and the employment of skilled labour has put forward the hypothesis of "skill biased technological change" (SBTC), which was initially proposed by Griliches (1969) and Welch (1970). The hypothesis supports the view that new technologies-to be implemented effectively and efficiently-require suitable skills. Berman et al. (1994) provided the earliest evidence on the existence of strong correlations between within industry skill upgrading and increased investment in both computer technology and R\&D in the US manufacturing sector between 1979 and 1989. A number of subsequent empirical studies confirmed the occurrence of a widespread SBTC in the US (see Autor et al. 1998; Katz and Autor 1999); France (Caroli and Van Reenen 2001); Spain (Aguirregabiria and AlonsoBorrego 2001); Italy (Piva et al. 2005) and other OECD countries (Machin and Van Reenen 1998). While most of the literature on the employment impacts of technological change centred on developed economies, recently some attention has also been devoted to middle-income and low-income developing countries (DCs).

\subsection{Innovation and employment}

Technological change in DCs is mainly imported and innovation is inherently linked to trade, foreign direct investments (FDI) and consequent international technology transfer (Acemoglu 2003; Piva 2003; Keller 2004). Globalization can imply a substantial technological up-grading in DCs through opening different channels. On the one hand, a developing country can implement embodied technological change (ETC) through the importation of "mature" machineries (including second-hand capital goods, see Barba Navaretti et al. 1998) from more industrialized countries. On the other hand, a late starter DC can enjoy the "last comer" benefit of jumping directly on a relatively new technology (Perkins and Neumayer 2005; Mitra and Jha 2015). ${ }^{1}$

In addition to their direct effect through ETC, imports and FDI inflows may generate technological spillovers in favour of domestic firms which can absorb new imported technologies through labour mobility, input-output relationships and reverse engineering (see Coe and Helpman 1995; Coe et al. 1997). Technological catch-up may also be induced by exporting to richer countries both through substituting/replacing outdated technologies in the exporting sectors, and through

\footnotetext{
1 An example can be the diffusion of mobile telecommunications in Sub-Sahara African countries, where the traditional telephone networks are largely limited to urban areas.
} 
the development of entirely new businesses characterized by process and product innovations (see Gkypali et al. 2015). The aim here is satisfying a more sophisticated demand coming from the industrialized countries ("learning by exporting”, see Keller 2001; Epifani 2003; Melitz 2003; Yeaple 2005).

All in all, technology transfer in favour of DCs involves productivity gains ${ }^{2}$ which can be harmful to the local DC's employment level. In particular, the dominant role of the imported ETC implying labour-saving process innovation can drastically reduce the domestic demand for labour. However, as discussed in Taylor (2004), the final employment outcome depends on the balance between labour productivity gains and output growth induced by domestic demand, trade and FDI. ${ }^{3}$

\subsection{Skill-biased technological change}

From a theoretical perspective both globalization (through the Heckscher-Ohlin theorem and its Stolper-Samuelson corollary, HOSS hereinafter) and technological change can be responsible for the observed pattern of increased relative demand for skilled labour in the developing world. Two processes are supposed to have opposite effects in this regard (see Lee and Vivarelli 2004, 2006a, b for an extensive analysis). On the one hand new technologies shift the labour demand in favour of more skilled workers. On the other hand, the HOSS mechanism predicts that a DC trading with skill-abundant richer economies should specialize in the production of unskilled-labour intensive goods, and therefore experience a relative increase in the demand for unskilled labour.

However, if the HOSS assumption of homogeneous production functions and identical technologies between countries is relaxed, then international openness may facilitate technology transfer from industrialized to developing countries. This implies that globalization and technological change are complementary rather than alternative mechanisms, resulting in an increase in the demand for skilled workers (see Lee and Vivarelli 2004, 2006b). Robbins (1996, 2003) and Robbins and Gindling (1999) call the effect of in-flowing technology resulting from trade liberalization the "skill-enhancing trade (SET) hypothesis". According to this hypothesis, trade accelerates the flows of physical capital (and embodied technology) to the South, inducing rapid adaptation to the skill-intensive technologies currently used in the North.

While a large body of the literature documented the relevance of the SBTC hypothesis for advanced countries, there is a dearth of empirical evidence for developing countries. Berman and Machin (2000, 2004) found evidence that SBTC has taken place rapidly from the developed world to at least the middle-income DCs. Meschi and Vivarelli (2009) also found a significant inequality-enhancing effect of trade with more advanced countries on middle-income DCs, possibly

\footnotetext{
2 On this the empirical evidence is unequivocal, see, for instance: (Coe and Helpman 1995; Helpman and Homaister, 1997; Mayer 2000; Schiff and Wang 2006).

${ }^{3}$ In his study, Taylor (2004) found out that in seven DCs out of eleven, output per capita in the traded goods sectors grew less rapidly than labour productivity, so implying job losses.
} 
related to technological transfer and skill-enhancing trade. Almeida (2009) reached similar conclusions using firm-level data for East Asia. ${ }^{4}$

The evidence from country-specific studies also points to the link between trade, FDI, technology transfer and skill-upgrading. For instance, Hanson and Harrison (1999), using data on Mexican manufacturing plants, found that firms receiving FDI acquire technology through licensing agreements or imported materials, and tend to hire more skilled workers (see also Feenstra and Hanson 1997). Similarly, Fajnzylber and Fernandes (2009) found that increased levels of international integration were associated with an increased demand for skilled labour in a crosssection of Brazilian firms. Görg and Strobl (2002) analysed a panel of manufacturing firms in Ghana over the ' $90 \mathrm{~s}$; their estimates revealed that while the purchase of foreign machinery for technological purposes significantly raised the relative demand for skilled labour, a greater participation in world markets via exporting activities was not found to have any effect.

Other studies have instead underlined the skill-enhancing effects of exporting activity, which makes the adoption of new technologies profitable for exporting firms (Yeaple 2005), induces quality upgrading (Verhoogen 2008; Fajnzylber and Fernandes 2009) and offers opportunities to acquire knowledge of international best practice (Bigsten et al. 2004).

Finally, at least for middle-income DCs, together with imported technologies and exports, domestic R\&D and innovation may play a relevant role, as it is the case for the most advanced countries. Meschi et al. (2011) showed that SET was an important factor in explaining the rise of the skilled labour cost share, but together with domestic R\&D. By the same token, Araújo et al. (2011) also found evidence in support of both the role of SET and domestic technology in determining the skillupgrading trend of the Brazilian manufacturing labour force.

As the review in the preceding paragraphs suggest, there is a dearth of empirical evidence on SBTC and employment effects in the context of low income countries. The empirical analysis undertaken in this paper attempts to fill this gap by investigating the SBTC and employment link in the context of Ethiopia. To this end the paper uses firm-level microdata and dynamic labour demand equations.

\section{The data}

The study relies on data from the Ethiopian "Annual Survey of Large and Medium Scale Manufacturing Industries" conducted by the Central Statistical Authority of Ethiopia. The survey covers 1940 enterprises, and has a total of 7050 observations for the period between 1996 and 2004. It includes formal private and public enterprises employing at least 10 employees. The enterprises are classified according to the "International Standard Classification", ISIC Rev.3. The final sample used in the empirical analysis comprises only private sector firms that have

\footnotetext{
${ }^{4}$ By the same token, Conte and Vivarelli (2011), using a direct measure of embodied technological transfer, found that imported skill-biased technological change is one of the determinants of the increase in the relative demand for skilled workers in DCs.
} 
reported to employing both production and administration workers. Firms that were not monitored for at least two consecutive years were also excluded from the final sample, since the main regression methodology (see Sect. 5) relies on lagged values of the regressors for identification. ${ }^{5}$ Table 8 in the Appendix reports the number of enterprises retained for the analysis carried out, highlighting the unbalanced nature of the data used.

The dataset contains a wide range of information about the enterprises generated from the 8-section survey questionnaire. Information on the type of activity of the enterprises, their employees and wages, inputs and output volumes, investments and license fees, and the major problems they face, are included in the dataset. All monetary variables are expressed in 1996 Birr, the Ethiopian currency, and have been deflated using GDP and CPI deflators as appropriate. Employment is measured as the number of workers in each quarter of the Ethiopian year. Total employment was therefore calculated as the annual average of these quarters. Employment is also divided into two categories, "administrative and technical employees" and "production workers". The former is defined as the salaried directors and managers, technicians, superintendents, research workers, draftsmen and designers, engineers, chemists, architects, accountants, book-keepers, office machine operators, receptionists, sales men, delivery personnel, guards and other office staff. As for the production workers, they include workers directly engaged in production i.e., persons engaged in fabricating, processing, assembling, maintenance, repair, janitorial, record keeping and other associated activities.

\section{The manufacturing sector in Ethiopia}

\subsection{Trade reform in Ethiopia}

Ethiopia's economy followed an import-substitution regime under the Imperial government, which lasted until 1974. Foreign capital played a major role in the process of industrialization during the 1950s up till the 1970s; foreign private (full or majority) ownership reached $52 \%$ by 1974 with a total of 143 firms (Shiferaw 2005).

The year 1974 marked the end of the monarchy era and the establishment of a military council (Derg) that adopted Socialist ideology. The regime continued to operate within the import-substitution strategy. The Derg nationalized all large and medium private manufacturing enterprises. The management of these enterprises was assigned to a small number of corporations that controlled prices and output quantities. Industrialization took place mainly through high tariffs, and the establishment of a few large enterprises that controlled factor markets and allowed state owned enterprises to gain preferential access to credit, foreign exchange and skilled labour. This came in parallel with a weakening of private manufacturing and the restriction of private investment.

\footnotetext{
5 This sample selection criterion has led to a reduction in the final sample size vis-à-vis other studies that have used this dataset, namely, Bigsten et al. (2009), and Bigsten and Gebreyeesus (2007).
} 
At the end of the 1980s, Ethiopia began to gradually move to a more marketoriented economy. With the new Transitional Government of Ethiopia (TGE) coming to power in 1991, the country's economic structure underwent major transformations vis-à-vis the preceding Derg era. The TGE undertook policy reform steps including privatization, trade opening and market deregulation. In June 1993, the government launched a structural adjustment program under the auspices of the World Bank and the African Development Fund. A comprehensive trade reform followed that aimed at dismantling quantitative restrictions and gradually reducing the levels of import tariffs and export taxes, as well as non-tariff barriers and import licensing requirements. Export promotion schemes were introduced. Custom tariffs were substantially reduced through a six-stage reform implemented between 1993 and 2003. In the first round, the maximum tariff was reduced from 230 to $80 \%$. The next rounds led to a further gradual reduction that reached $35 \%$ in 2003 (Bigsten et al. 2009). In 2001 the Export Trade Duty Incentive Scheme was established. It included duty draw-backs, vouchers, and bonded manufacturing warehouses, where exporters are refunded $100 \%$ of any duty paid on raw materials. To further encourage exporters to acquire foreign technology and expertise, the government also issued directives in 2004 to reduce taxes and other costs on salaries paid to foreign experts (Bigsten and Gebreeyesus 2007). Even though the post 1991 period witnessed significant economic liberalization, it is important to emphasize that the State continued to play a prominent role in the Ethiopian economy over this period. Land remains a public property in Ethiopia; and the State still fully controls some key sectors of the economy such as telecommunication and IT, while it plays a dominant role in other sectors such as banking, insurance and transportation. The prevailing development strategy is also spearheaded by the State. Indeed, the growth performance witnessed in recent years is driven by extensive public sector investments, particularly in the energy and road transport sectors (see World Bank 2013a, b; IMF 2013). ${ }^{6}$

Figure 1 shows the GDP share of both exports and imports, which increased as a result of these changes in the country's trade policy. Exports increased from $9.3 \%$ of GDP in 1996 to $14.9 \%$ in 2004, an increase of around $60 \%$. Imports increased from $16.3 \%$ in 1993 to $31.6 \%$, a much a larger increase of $94 \%$, hence the gap between exports and imports is increasing. It is worth noting in this respect that ICT imports' share of total imports has been increasing rapidly, where ICT imports formed $5 \%$ of all good imports in 2000 and increased to around $9 \%$ in 2004, indicating an increasing demand for high technology communication and computing systems that possibly reflect an upgrading in the production and/or management processes in the various economic sectors in Ethiopia.

Trade liberalization was accompanied by financial market liberalization and a large devaluation of the Birr. Since then, the exchange rate has been increasingly market driven. Most price controls and restrictions on private investments have also been lifted and a large wage of privatization took place. This has also led to the increase in FDI inflows as presented in Fig. 2 below.

\footnotetext{
${ }^{6}$ See also recent commentaries by The Economist such as http://www.economist.com/news/middle-eastand-africa/21584037-government-expands-mobile-phone-network-tightens-its-grip-out-reach.
} 


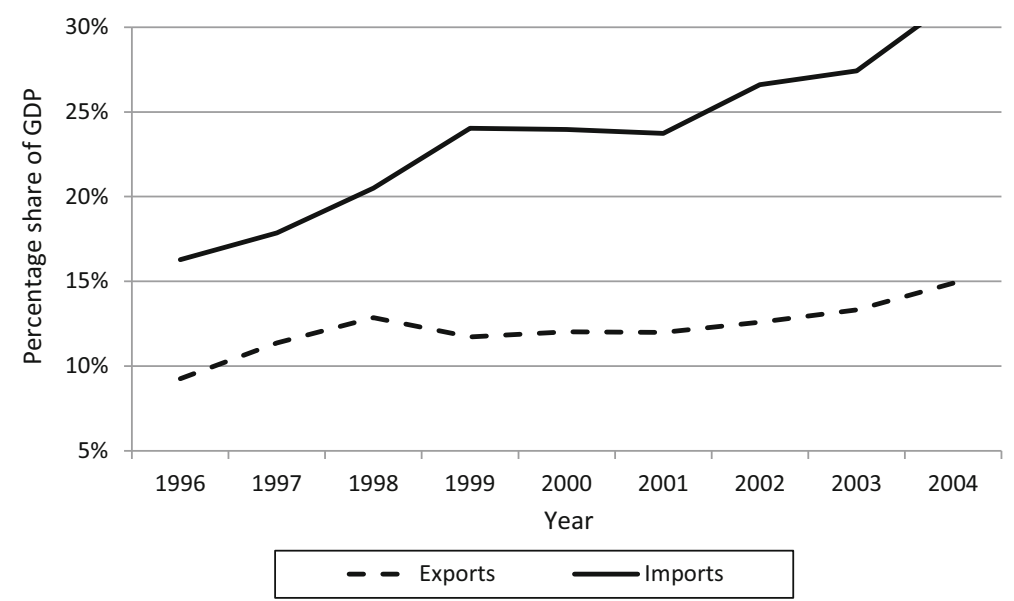

Fig. 1 Ethiopia's exports and imports of goods and services (\% of GDP), Source: World Development Indicators (WDI)-2013

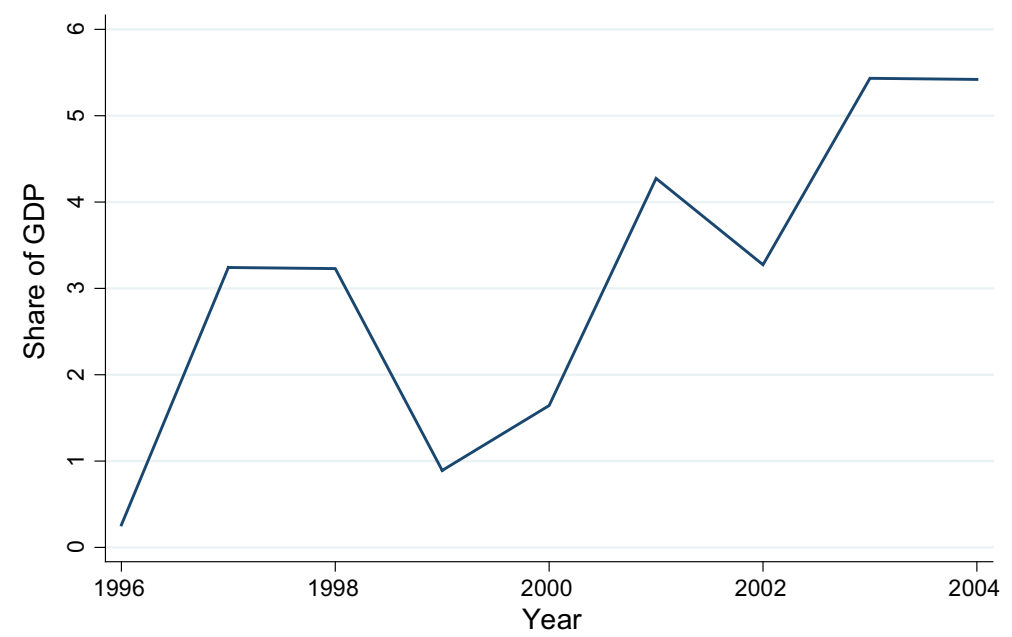

Fig. 2 FDI inflows as percentage of GDP (1996-2004), Source: World Development Indicators (WDI)2013

There was a drop in these inflows between 1998 and 2000 as a result of the Eritrean-Ethiopian war, but they increased rapidly after the end of the conflict and peaked in 2003-2004 at around \$550million. ${ }^{7}$ Of the FDI projects licensed by 2003, $46.6 \%$ were in manufacturing and processing; $40.7 \%$ in trade, hotels and tourism; and $12.7 \%$ in agriculture and mining (UNCTAD 2004).

${ }^{7}$ Figure from UNCTAD stat. 


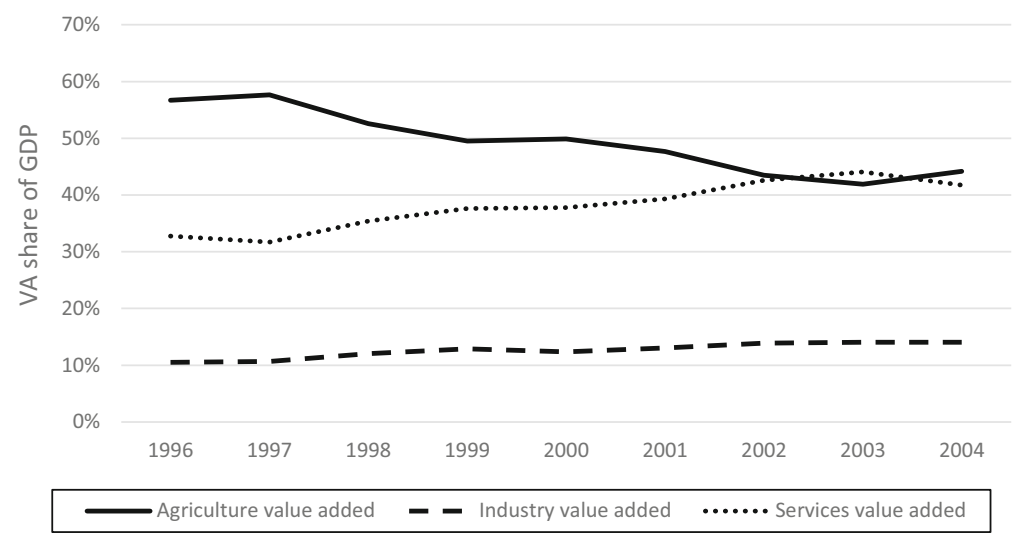

Fig. 3 Value added of Ethiopian economic sectors as percentage of GDP (1996-2004), Source: World Development Indicators (WDI), 2013

\subsection{The Ethiopian manufacturing sector: size and employment}

Ethiopia's industrial base remains to be quite small compared to other developing countries, as well as with respect to other national economic sectors. The GDP share of the industrial sector's value added increased from $10.7 \%$ in 1996 to $14.1 \%$ in 2004 as Fig. 3 below depicts.

However, this share is still much lower than sub-Saharan African average of $31.8 \%$ (Bigsten and Gebreeyesus 2007). The share of agriculture in the national value added has been decreasing steadily, though it still constitutes more than $40 \%$ of the country's output value added, while the share of industry and services have both been rising at similar rates.

The share of manufacturing in GDP is another indicator of the country's underdeveloped manufacturing base, which formed an average of only $5.4 \%$ of GDP for the period 1996-2004, rising from 5.13\% in 1996 and reaching a peak in 2001 (5.72\%), and declining to $5.32 \%$ in $2004 .{ }^{8}$ Table 1 below reports the distribution of firms across the two-digit aggregation of the country's manufacturing sectors. The highest share of firms is within the food and beverages sector, followed by furniture production. ${ }^{9}$

Total employment and the share of skilled employment have steadily increased during the period 1996-2004. This was however happening in parallel with a decrease in average employment, which reflects a decline in firm size. The share of skilled workers witnessed a sharp increase from $27.7 \%$ in 1996 to $35.8 \%$ in 1997.

\footnotetext{
8 Figures from WDI, 2013.

9 The largest output share is also that of the food products and beverages sector. The food, beverages, and textile sectors make up the largest shares of employment of around $27 \%$ each; thus together accounting for more than half of manufacturing employment. Contributing to only $9 \%$ of manufacturing output, and containing more than a quarter of employment, the textile sector seems to remain labour intensive. In contrast, the tanning and dressing leather contributes almost the same share of output $(8.8 \%)$, but contains only $8 \%$ of labour; therefore, this sector seems to be moving away from traditional labour intensive production processes and towards more mechanized systems. Similar analysis can also be made looking at the non-metallic mineral products sector.
} 
Table 1 Distribution of firms by 2 digit ISIC (\%)

\begin{tabular}{lrrr}
\hline Manufacturing sector & $\begin{array}{r}\text { Total } \\
\text { firms }\end{array}$ & $\begin{array}{r}\text { Share of } \\
\text { output }\end{array}$ & $\begin{array}{r}\text { Share of } \\
\text { employment }\end{array}$ \\
\hline Food products and beverages & 28.5 & 40.2 & 27.1 \\
Tobacco products & 0.1 & 3.6 & 1.1 \\
Textiles & 4.3 & 9.0 & 27.1 \\
Wearing apparel; dressing and dyeing of fur & 3.5 & 0.7 & 4.6 \\
Tanning and dressing of leather & 7.1 & 8.8 & 8.1 \\
Wood and of products of wood and cork & 2.4 & 0.6 & 1.5 \\
Paper and paper products & 0.9 & 2.4 & 1.6 \\
Publishing, printing and reproduction of recorded media & 6.6 & 2.8 & 4.8 \\
Chemicals and chemical products & 5.1 & 6.1 & 4.4 \\
Rubber and plastics products & 3.8 & 5.1 & 3.9 \\
Other non-metallic mineral products & 11.5 & 8.4 & 6.2 \\
Basic metals & 1.0 & 4.5 & 1.5 \\
Fabricated metal products, except machinery and equipment & 6.6 & 1.7 & 2.7 \\
Machinery and equipment & 1.5 & 0.1 & 0.3 \\
Electrical machinery and apparatus. & 0.2 & 0.0 & 0.1 \\
Motor vehicles, trailers and semi-trailers & 1.0 & 4.6 & 1.0 \\
Furniture & 15.7 & 1.5 & 4.1 \\
Total & 100.0 & 100.0 & 100.0 \\
\hline Authors' & & \\
\hline
\end{tabular}

Authors' calculations from the Annual Survey of Manufacturing Industry

It has remained more or less stable since then, with some fluctuations around its 1997 level. The overall change in the skill mix may be indicative of the presence or, at least, the beginning of skill bias within the manufacturing sector. Higher levels of total employment seem to be associated with higher shares of foreign ownership in Ethiopian manufacturing enterprises overall, as can be seen from Table 2 below. Higher share of foreign ownership is also generally associated with higher average number of administrative or skilled workers.

\section{The empirical model}

The starting point of the empirical analysis is a standard demand for labour, augmented with variables concerning our focus dimensions: technology and globalization. ${ }^{10}$ Moreover, relevant costs in labour adjustments and persistence in the employment evolution call for a dynamic setting (as standard in the literature, see Arellano and Bond 1991; for a recent application see Lachenmaier and Rottmann 2011); therefore, a lagged employment variable is added to our demand for labour, that takes the following final extended form:

\footnotetext{
10 The choice of this specification is consistent with previous empirical literature studying the employment effects of technological change and assuming a perfect competition setting (see Van Reenen 1997; Conte and Vivarelli 2011).
} 
Table 2 Mean total employment, administration and production workers by foreign share in private enterprises

\begin{tabular}{lcll}
\hline $\begin{array}{l}\text { Foreign share in paid up } \\
\text { capital (\%) }\end{array}$ & $\begin{array}{l}\text { Mean number } \\
\text { of employees }\end{array}$ & $\begin{array}{l}\text { Mean admin } \\
\text { workers }\end{array}$ & $\begin{array}{l}\text { Mean product } \\
\text { workers }\end{array}$ \\
\hline 0 & 41.4 & 13.7 & 27.4 \\
$0-10$ & 70.5 & 29.3 & 41.2 \\
$10-20$ & 91.9 & 34.5 & 57.4 \\
$20-40$ & 121.8 & 77.8 & 44.0 \\
$40-60$ & 60.0 & 14.1 & 45.9 \\
More than 60 & 142.2 & 63.7 & 78.5 \\
\hline
\end{tabular}

Authors' calculations from the Annual Survey of Manufacturing Industry

$$
\begin{aligned}
\mathrm{EMP}_{\mathrm{it}}= & \alpha+\beta \mathrm{EMP}_{\mathrm{it}-1}+\delta \mathrm{W}_{\mathrm{it}}+\gamma \mathrm{Y}_{\mathrm{it}}+\eta \mathrm{INV}_{\mathrm{it}}+\mu \mathrm{FOR}_{\mathrm{it}} \\
& +\lambda \mathrm{EXP}_{\mathrm{it}}+\omega \mathrm{LOC}_{\mathrm{it}}+\left(\mathrm{u}_{\mathrm{it}}+\varepsilon_{\mathrm{i}}\right)
\end{aligned}
$$

All variables-apart from dummies-are expressed in natural logarithms. Standard to panel data analysis, the error term is composed of the idiosyncratic error component $\left(\mathrm{u}_{\mathrm{it}}\right)$ and the time invariant firm fixed effects component $\left(\varepsilon_{\mathrm{i}}\right)$. EMP is the number of employed workers in firm $i$ at time $t$. W represents the real wages of workers, and $\mathrm{Y}$ is the real output of each firm. INV captures the share of investment out of total output. A positive coefficient of this variable is an indicator that the mechanism of compensation through investment is indeed at work. FOR represents the share of foreign ownership in a firm at a given time period. It is a measure of the degree of foreign investment that is expected to be a channel of technology transfer through the full or partial involvement of MNCs in the production processes of their partner enterprises. In this way, we will also be able to evaluate the skill-biased impact of FDI. A positive and significant coefficient of this variable would indicate that there is either a direct employment effect manifested through the fact that the MNCs themselves employ workers, or an indirect effect through increased demand for local suppliers' products that could contribute to increasing employment in local firms as well (Dunning and Fontanier 2007). EXP is the export to output ratio. It is used to test whether exporting firms are in fact expanding their production.

As mentioned earlier, exporting firms in middle and low income countries can be in fact "learning by exporting" (Keller 2001), through obtaining efficiency gains, and acquiring knowledge of international best practices (Vivarelli 2014). Positive and significant results for this variable would indicate that exporters within the Ethiopian manufacturing sector are indeed benefitting from this channel of technology transfer. LOC is a dummy variable for location. It takes the value of one if the firm is located in and around Addis Ababa, the capital, and zero if outside of the capital region. It is expected that larger and more technologically advanced firms are located in the capital area that is the business and financial centre in the country. Consequently, their location would have an employment enhancing effect, through higher competitiveness. 
As the paper also aims to look into the phenomenon of skill bias within the Ethiopian manufacturing sector, the empirical model is extended to capture this effect, if present. This is performed through defining a separate labour demand equation for each group of skilled and unskilled workers. Equation (1) is therefore expressed for both types of labour through the following form:

$$
\begin{aligned}
\mathrm{USL}_{\mathrm{it}}= & \alpha+\beta \mathrm{USL}_{\mathrm{it}-1}+\delta \mathrm{USW}_{\mathrm{it}}+\gamma \mathrm{Y}_{\mathrm{it}}+\eta \mathrm{INV}_{\mathrm{it}}+\mu \mathrm{FOR}_{\mathrm{it}}+\lambda \mathrm{EXP}_{\mathrm{it}} \\
& +\omega \mathrm{LOC}_{\mathrm{it}}+\left(\mathrm{u}_{\mathrm{it}}+\varepsilon_{\mathrm{i}}\right) \\
\mathrm{SL}_{\mathrm{it}}= & \alpha+\beta \mathrm{SL}_{\mathrm{it}-1}+\delta \mathrm{SW}_{\mathrm{it}}+\gamma \mathrm{Y}_{\mathrm{it}}+\eta \mathrm{INV}_{\mathrm{it}}+\mu \mathrm{FOR}_{\mathrm{it}}+\lambda \mathrm{EXP}_{\mathrm{it}} \\
& +\omega \mathrm{LOC}_{\mathrm{it}}+\left(\mathrm{u}_{\mathrm{it}}+\varepsilon_{\mathrm{i}}\right)
\end{aligned}
$$

where USL and SL are the numbers of unskilled and skilled labour, respectively, measured by the amounts of production $v s$ administrative workers; and USW and SW are the real wages of unskilled and skilled labour. Table 3 reports some descriptive statistics of the dependent and independent variables used in all three regression equations.

The main advantage of using a two-equation setting rather than the standard cost share unique equation is that it allows for studying relative versus absolute skill bias. Absolute skill bias would appear when technology and openness related variables display a positive and significant coefficient for skilled workers and a negative or not significant coefficient for unskilled workers, while relative skill bias would appear when the coefficients for both skilled and unskilled workers are positive and significant but differ in magnitude, with the coefficient for unskilled workers being lower (this difference turning out to be statistically significant). In addition, this setting is more informative in exploring the employment dynamics of the different categories of workers separately.

The presence of firm-specific effects causes a correlation between the lagged dependent variable (EMP ${ }_{\text {it-1 }}$, USL $\mathrm{USt}_{\mathrm{it}-1}$ or $\mathrm{SL}_{\mathrm{it}-1}$ ) and the individual fixed effect $\varepsilon_{\mathrm{i}}$. Therefore, using the pooled OLS methodology would lead to upwardly biased and

Table 3 Descriptive statistics of regression variables

\begin{tabular}{lllllll}
\hline & $\mathrm{N}$ & Mean & Median & Min & Max & Std. dev \\
\hline Total employment & 4038 & 47 & 18 & 2 & 2759 & 122.07 \\
Total wage & 4035 & 3725.27 & 3119.71 & 32.07 & 46162.55 & 2588.93 \\
Output & 3986 & $4,273,111$ & 481,632 & 3662 & $268,000,000$ & $14,700,000$ \\
Investment/output ratio & 4038 & 0.19 & 0 & 0 & 91.73 & 1.94 \\
Location dummy & 4038 & 0.64 & 1 & 0 & 1 & 0.48 \\
Foreign ownership share & 4038 & 0.04 & 0 & 0 & 1 & 0.18 \\
Export/output ratio & 4038 & 0.02 & 0 & 0 & 1.34 & 0.13 \\
Production workers & 4038 & 31 & 12 & 0 & 2433 & 94.78 \\
Wage of production workers & 3995 & 3424.40 & 2869.03 & 30.39 & 26458.86 & 2247.71 \\
Administrative workers & 4038 & 17 & 5 & 0 & 701 & 42.35 \\
Wage of administrative workers & 3928 & 4615.09 & 3457.97 & 41.26 & 85169.91 & 4401.61 \\
\hline
\end{tabular}


inconsistent coefficients of the lagged dependent variable, with a larger bias as the variance of the unobserved effect increases (Hsiao 1986). Furthermore, the dynamic specification of the model implies that the assumption of strict exogeneity of the explanatory variables does not hold due to the presence of an endogenous first-order lagged dependent variable. Obtaining consistent and efficient estimators includes first transforming the original equations to eliminate the fixed effects and then applying instrumental variables estimations for the parameter of the lagged endogenous variable (Halaby 2004). Anderson and Hsiao (1982) have developed a formulation for obtaining consistent FE-IV estimators by resorting to first differencing in order to eliminate the unobserved effect, and then two lags and beyond to instrumentalise the lagged dependent variable. However, more radical efficiency improvements have been obtained by Arrellano and Bond (1991), using GMM techniques as an alternative to the Anderson and Hsiao approach. In their model, the instrument matrix includes all previous level values of the lagged dependent variable, where they obtain the GMM-DIFF estimator. However, the GMM-DIFF estimator has been found to be weak in cases when: (1) there is a strong persistence over time, where the instruments are weakly correlated with the first difference variables, and (2) cross-sectional variability dominates time variability (Bond et al. 2001). Blundell and Bond (1998) have then put forward an efficiency improvement to the GMM-DIFF model by using additional moment conditions and obtaining the system GMM or GMM-SYS. In particular, they use moment restrictions of a simultaneous system of first-differenced equations and the equations in level. In the first-differenced equations they use the lagged level values of the variables as instruments (similar to the GMM-DIFF estimator), and in the level equations they use differences as instruments. In the present empirical study, the GMM-SYS is used since it fits best with the characteristics of the panel data used and the nature of the empirical model. In particular, our longitudinal data are characterized by a larger cross-sectional (between variance equal to 1.003) than time variability (within variance equal to 0.1144 ) and-as Table 4 below depictsby a time persistence that is obvious for all the three dependent variables. These features of the data are exactly those that make GMM-SYS as preferred to GMMDIF (see Blundell and Bond 1998).

Moreover, since our baseline specification (1) may be affected by endogeneity that goes beyond the lagged dependent variable (for instance, it may well be the case that wage and employment decisions are jointly and simultaneously adopted, as well as the output and investment decisions), the GMM-SYS orthogonality procedure will be applied to all the dependent variables, using one-lagged instruments when

Table 4 Time persistence in the employment time series

\begin{tabular}{llll}
\hline & Total employment & Unskilled workers & Skilled workers \\
\hline AR(1) & $0.896^{* * *}$ & $0.830^{* * *}$ & $0.860^{* * *}$ \\
& $(0.000)$ & $(0.000)$ & $(0.000)$ \\
\hline
\end{tabular}

$* * *, * *$, and $*$ indicate the statistical significance at the 1,5 , and $10 \%$, respectively 
necessary. Finally, time and sector dummies will be included to control for unobserved shocks that may affect the variables.

As noted in Sect. 3, the estimation sample used is unbalanced in nature. This poses some challenges in that some of the data transformations undertaken for the SYS-GMM may magnify gaps in the data resulting in possibly biased estimators. However, we provide OLS and FE estimators for proper robustness checks.

\section{Results}

The results from our empirical analysis are reported in Tables 5, 6 and 7 below. Table 5 presents the OLS, FE and SYS-GMM estimators for the total employment equation. Although OLS is expected to result in upward biased estimates in the presence of firm specific effects and a dynamic specification, it forms an upper bound for the value of the estimate of lagged endogenous variable obtained in SYSGMM. Similarly, the FE results are presented to provide a lower bound for the value of the mentioned estimator, since the fixed effects regression produces downward biased results.

Looking at the last column of Table 5, the SYS-GMM shows a positive and significant value of lagged total employment coefficient, further asserting the persistence in the time series. The magnitude of this coefficient lies within the upper and lower bounds set by the OLS and FE estimators, respectively. The total wage coefficient shows a negative and significant value, which is in line with the expected sign indicating a negative relationship between labour demand and wages.

The rest of the regressors show positive coefficients reflecting employmentenhancing effects to varying levels of significance. The output explanatory variable shows that an expansion in output requires higher levels of employment. Similarly, the positive sign of the investment variable indicates that as the share of investment in total output increases, the demand for labour rises. This is a manifestation that at least part of firms' profits are being used for expanding their production capacity, thus the compensation channel via new investments might be at work in the manufacturing sector of Ethiopia (see Sect. 2). The location dummy variable is found to be highly significant and suggests that firms located in the capital region hire more workers vis-à-vis their counterparts in other regions. The Foreign ownership variable is also found to be weakly significant suggesting that firms with higher foreign share have a greater tendency to expand. Involvement in exporting activity is also found to have an employment enhancing effect, albeit being weakly significant, as can be gathered from the coefficient of the export ratio variable.

In terms of relative magnitude, it appears that the export variable has the highest impact since its coefficient is of the highest magnitude. However, this effect is weakly $(10 \%)$ significant. The location dummy has the second highest coefficient and is significant at $1 \%$.

A number of validity tests have been conducted to check the performance of the model and robustness of the results. The Wald test was used to test the overall significance of the independent variables. It rejected the null hypothesis of insignificant coefficients, thus confirming the joint significance of the variables and 
Table 5 Regression results from the total employment equation

\begin{tabular}{|c|c|c|c|}
\hline $\begin{array}{l}\text { Dependent variable: total } \\
\text { employment }\end{array}$ & OLS & FE & $\begin{array}{l}\text { SYS- } \\
\text { GMM }\end{array}$ \\
\hline Lagged total employment & $\begin{array}{l}0.710^{* * * *} \\
(0.0112)\end{array}$ & $\begin{array}{l}0.160 * * * \\
(0.0191)\end{array}$ & $\begin{array}{l}0.352 * * * \\
(0.0653)\end{array}$ \\
\hline Total wage & $\begin{array}{l}-0.144 * * * \\
(0.0171)\end{array}$ & $\begin{array}{l}-0.313 * * * \\
(0.0223)\end{array}$ & $\begin{array}{l}-0.262^{*} \\
(0.1450)\end{array}$ \\
\hline Real output & $\begin{array}{l}0.177^{* * *} \\
(0.0076)\end{array}$ & $\begin{array}{l}0.184 * * * \\
(0.0114)\end{array}$ & $\begin{array}{l}0.372 * * * \\
(0.0593)\end{array}$ \\
\hline Investment/output ratio & $\begin{array}{l}0.00814 \\
(0.0071)\end{array}$ & $\begin{array}{l}-0.0146 * * \\
(0.0074)\end{array}$ & $\begin{array}{l}0.0241 * * * \\
(0.0064)\end{array}$ \\
\hline Location dummy & $\begin{array}{l}0.0608 * * * \\
(0.0174)\end{array}$ & $\begin{array}{l}0.0521 \\
0.0795)\end{array}$ & $\begin{array}{l}0.188 * * * \\
(0.0484)\end{array}$ \\
\hline Foreign ownership share & $\begin{array}{l}0.0879 * * \\
(0.0412)\end{array}$ & $\begin{array}{l}-0.0236 \\
(0.0537)\end{array}$ & $\begin{array}{l}0.170^{*} \\
(0.0996)\end{array}$ \\
\hline Export/output ratio & $\begin{array}{l}0.0161 \\
(0.0626)\end{array}$ & $\begin{array}{l}-0.123 \\
(0.1700)\end{array}$ & $\begin{array}{l}1.165^{*} \\
(0.5970)\end{array}$ \\
\hline Constant & $\begin{array}{l}-0.417 * * * \\
(0.1150)\end{array}$ & $\begin{array}{l}2.751 * * * \\
(0.2240)\end{array}$ & $\begin{array}{l}-1.054 \\
(0.9290)\end{array}$ \\
\hline Time dummies & Yes & Yes & Yes \\
\hline Sector dummies & Yes & No & Yes \\
\hline Observations & 2816 & 2816 & 2816 \\
\hline Number of firms & & 865 & 865 \\
\hline R-squared & 0.855 & 0.693 & \\
\hline Adjusted R-squared & 0.853 & & \\
\hline $\operatorname{AR}(1)$ & & & $\begin{array}{l}-7.51 * * * \\
(0.000)\end{array}$ \\
\hline $\mathrm{AR}(2)$ & & & $\begin{array}{l}0.896 \\
(0.370)\end{array}$ \\
\hline Wald test chi2 & & & $\begin{array}{l}2131 * * * \\
(0.000)\end{array}$ \\
\hline Hansen test & & & $\begin{array}{l}102.5 \\
(0.439)\end{array}$ \\
\hline Number of instruments & & & 131 \\
\hline
\end{tabular}

Robust standard errors (for coefficients) and p-values (for tests) in brackets

$* * *, * *$, and $*$ indicate the statistical significance at the 1,5 , and $10 \%$, respectively

the robustness of the overall results. The Hansen test for over-identifying restrictions, where the null hypothesis is that of adequate instruments, failed to reject the null, thus confirming the adequacy of the instruments used. In addition, the Arellano and Bond (AR) test for autocorrelation was performed, which is found to support the consistency of the GMM estimators using t-2 instruments.

Another question this paper attempts to address is whether differential employment enhancing effect exists in the allocation of skilled and unskilled 
Table 6 Regression results from the skill specific employment equations

\begin{tabular}{|c|c|c|c|c|c|c|}
\hline \multirow[t]{2}{*}{ Dependent variable } & \multicolumn{3}{|c|}{ Unskilled workers } & \multicolumn{3}{|c|}{ Skilled workers } \\
\hline & OLS & $\mathrm{FE}$ & $\begin{array}{l}\text { SYS- } \\
\text { GMM }\end{array}$ & OLS & $\mathrm{FE}$ & $\begin{array}{l}\text { SYS- } \\
\text { GMM }\end{array}$ \\
\hline $\begin{array}{l}\text { Lagged production } \\
\text { worker } \\
\text { employment }\end{array}$ & $\begin{array}{l}0.606 * * * \\
(0.0130)\end{array}$ & $\begin{array}{l}0.117 * * * \\
(0.0203)\end{array}$ & $\begin{array}{l}0.295 * * * \\
-0.0452\end{array}$ & & & \\
\hline $\begin{array}{l}\text { Production worker } \\
\text { wages }\end{array}$ & $\begin{array}{l}-0.232 * * * \\
(0.0198)\end{array}$ & $\begin{array}{l}-0.334 * * * \\
(0.0252)\end{array}$ & $\begin{array}{l}-0.448 * * * \\
(0.0508)\end{array}$ & & & \\
\hline $\begin{array}{l}\text { Lagged admin } \\
\text { worker } \\
\text { employment }\end{array}$ & & & & $\begin{array}{l}0.696 * * * \\
(0.0125)\end{array}$ & $\begin{array}{l}0.0790 * * * \\
(0.0209)\end{array}$ & $\begin{array}{l}0.280 * * * \\
(0.0547)\end{array}$ \\
\hline $\begin{array}{l}\text { Admin worker } \\
\text { wages }\end{array}$ & & & & $\begin{array}{l}-0.0996 * * * \\
(0.0180)\end{array}$ & $\begin{array}{l}-0.253 * * * \\
(0.0233)\end{array}$ & $\begin{array}{l}-0.311 * * * \\
-0.0486\end{array}$ \\
\hline Real output & $\begin{array}{l}0.232 * * * \\
(0.0092)\end{array}$ & $\begin{array}{l}0.202 * * * \\
(0.0158)\end{array}$ & $\begin{array}{l}0.406 * * * \\
(0.0586)\end{array}$ & $\begin{array}{l}0.183 * * * \\
(0.0099)\end{array}$ & $\begin{array}{l}0.151 * * * \\
(0.0164)\end{array}$ & $\begin{array}{l}0.462 * * * \\
(0.0505)\end{array}$ \\
\hline $\begin{array}{l}\text { Investment/output } \\
\text { ratio }\end{array}$ & $\begin{array}{l}0.00652 \\
(0.0095)\end{array}$ & $\begin{array}{l}-0.0143 \\
(0.0106)\end{array}$ & $\begin{array}{l}0.0256 * * * \\
(0.0088)\end{array}$ & $\begin{array}{l}0.0228 * * \\
(0.0103)\end{array}$ & $\begin{array}{l}-0.0117 \\
(0.0110)\end{array}$ & $\begin{array}{l}0.0300 * * * \\
(0.0065)\end{array}$ \\
\hline Location dummy & $\begin{array}{l}0.0469 * * \\
(0.0227)\end{array}$ & $\begin{array}{l}-0.0855 \\
(0.1110)\end{array}$ & $\begin{array}{l}0.161 * * * \\
(0.0438)\end{array}$ & $\begin{array}{l}0.116^{* * *} \\
(0.0250)\end{array}$ & $\begin{array}{l}0.337 * * * \\
(0.1160)\end{array}$ & $\begin{array}{l}0.312 * * * \\
(0.0548)\end{array}$ \\
\hline $\begin{array}{l}\text { Foreign ownership } \\
\text { share }\end{array}$ & $\begin{array}{l}0.0913 * \\
(0.0540)\end{array}$ & $\begin{array}{l}-0.0365 \\
(0.0753)\end{array}$ & $\begin{array}{l}0.168 \\
(0.1160)\end{array}$ & $\begin{array}{l}0.111^{*} \\
(0.0585)\end{array}$ & $\begin{array}{l}-0.062 \\
(0.0782)\end{array}$ & $\begin{array}{l}0.243 * * \\
(0.1230)\end{array}$ \\
\hline Export/output ratio & $\begin{array}{l}-0.0027 \\
(0.0823)\end{array}$ & $\begin{array}{l}-0.07 \\
(0.2380)\end{array}$ & $\begin{array}{l}1.144 * \\
(0.6570)\end{array}$ & $\begin{array}{l}0.0509 \\
(0.0891)\end{array}$ & $\begin{array}{l}-0.166 \\
(0.2470)\end{array}$ & $\begin{array}{l}1.136 \\
(0.7540)\end{array}$ \\
\hline Constant & $\begin{array}{l}-0.467 * * * \\
(0.1460)\end{array}$ & $\begin{array}{l}2.413 * * * \\
(0.2840)\end{array}$ & $\begin{array}{l}-0.369 \\
(0.7590)\end{array}$ & $\begin{array}{l}-1.070 * * * \\
(0.1400)\end{array}$ & $\begin{array}{l}1.724 * * * \\
(0.2830)\end{array}$ & $\begin{array}{l}-2.473 * * * \\
(0.5850)\end{array}$ \\
\hline Time dummies & Yes & Yes & Yes & Yes & Yes & Yes \\
\hline Sector dummies & Yes & No & Yes & Yes & No & Yes \\
\hline Observations & 2816 & 2816 & 2816 & 2816 & & 2816 \\
\hline Number of firms & & & 865 & & & 865 \\
\hline R-squared & 0.768 & 0.572 & & 0.789 & 0.443 & \\
\hline Adjusted R-squared & 0.765 & & & 0.787 & & \\
\hline $\operatorname{AR}(1)$ & & & $\begin{array}{l}-8.227 * * * \\
(0.000)\end{array}$ & & & $\begin{array}{l}-9.661 * * * \\
(0.000)\end{array}$ \\
\hline $\operatorname{AR}(2)$ & & & $\begin{array}{l}1.411 \\
(0.158)\end{array}$ & & & $\begin{array}{l}1.466 \\
(0.143)\end{array}$ \\
\hline Wald test $\mathrm{chi}^{2}$ & & & $\begin{array}{l}1384 * * * \\
(0.000)\end{array}$ & & & $\begin{array}{l}1266^{* * * *} \\
(0.000)\end{array}$ \\
\hline Hansen & & & $\begin{array}{l}122.8 \\
(0.513)\end{array}$ & & & $\begin{array}{l}129.1 \\
(0.382)\end{array}$ \\
\hline $\begin{array}{l}\text { Number of } \\
\text { instruments }\end{array}$ & & & 154 & & & 154 \\
\hline
\end{tabular}

Robust standard errors (for coefficients) and $p$ values (for tests) in brackets

$* * *, * *$, and $*$ indicate the statistical significance at the 1,5 , and $10 \%$, respectively 
Table 7 t-statistic for comparing coefficients of the two equations

$* * *, * *$, and * indicate the statistical significance at the 1 , 5 , and $10 \%$, respectively

\begin{tabular}{lll}
\hline Variable & T-statistic & $p$ value \\
\hline Real output & 0.724 & 0.25 \\
investment/output ratio & 0.401 & 0.50 \\
Location dummy & $2.152^{* *}$ & 0.03 \\
Foreign ownership share & 0.444 & 0.50 \\
Export/output ratio & 0.008 & 0.50 \\
\hline
\end{tabular}

labour. Table 6 shows the results of the second set of regressions, where the demand for labour was studied for skilled labour and unskilled labour separately. As mentioned earlier, having two equations allows us to observe the relative versus absolute skill bias, if any.

Looking at the SYS-GMM results for both unskilled and skilled workers, the lagged employment variable is positive and significant for both types of workers. This, as in the case of total employment, affirms the time persistence of the series. In addition, the coefficients of both variables lie within the bounds set by OLS and FE results. The wage explanatory variables are also significant and in line with the expected negative sign. It is worth noting here that in terms of magnitude, the coefficient of unskilled workers is higher than that of skilled workers. A possible explanation for this may be that the demand for unskilled workers is more elastic given the ease with which such workers can be substituted vis-à-vis their skilled counterparts.

The coefficient of the output variable is positive and significant for both types of workers, with a slightly higher magnitude for skilled workers. The difference between these two coefficients however proved not statistically significant (refer to Table 7). Therefore, no conclusion regarding the presence of a relative skill bias can be asserted here. The investment variable shows similar results, positive and significant for both skilled and unskilled labour, with a higher magnitude for skilled labour. However, also in this case, the $t$ test for the significance of the difference between the two values is not significant (see Table 7, second row).

Proximity to the capital city is found to increase the demand for skilled labour more than the demand for unskilled workers (with both the coefficients turning out highly significant). This difference between the magnitudes of the location variable is significant at the $95 \%$ level of confidence (see Table 7, third row). Therefore, location does exhibit a relative skill bias effect in that firms located in the capital and its vicinity not only hire more workers, but they have the tendency to hire more skilled workers.

The share of foreign ownership is found to have significant effects only for skilled workers. Therefore, the employment enhancing effect of foreign ownership observed in the total employment equation stems mostly from the effect on the demand for skilled labour. ${ }^{11}$ This leads us to the conclusion that firms with higher shares of foreign ownership exhibit an absolute skill bias effect, indicating that the FDI channel of technology transfer is at work in Ethiopia.

\footnotetext{
11 The $t$ test for the difference between the two coefficients of this variable is not found to be statistically significant due to the coefficient for unskilled labour being not significant.
} 
The export variable, contrary to expectations pertaining to a possible skill bias, is found to be barely significant for unskilled labour but insignificant for skilled labour. This is to say that the positive effect on total employment observed earlier originates mainly from higher demand for unskilled rather than skilled labour. Therefore, the process of "learning by exporting" is not obvious in Ethiopia, at least not for the time period considered, turning out to be characterized by a dominant role of an HOSS effect, with Ethiopian exports still stemming from traditional and low-skill intensive manufacturing sectors.

Looking at the results of Table 6 from another perspective, we can analyse the results of each type of labour separately. For unskilled labour, the variable that appears to have the highest employment enhancing effect is the export variable. This indicates that the manufactured goods being exported follow production techniques that have not (yet) adopted more advanced labour-saving technologies.

The most prominent contributor to increasing demand for skilled labour appears to be real output. This however does not necessarily allow us to make conclusions regarding the technology levels of these expanding firms. As noted earlier, however, there is evidence of an obvious skill-bias associated with foreign ownership and with the location in and around the capital city.

The various diagnostic tests showed evidence supporting the robustness of the results. The Wald test rejected the null of insignificant estimator coefficients for both unskilled and skilled labour demand equations. The Hansen test never rejected the null for either of the two equations, asserting the suitability of the instruments used. The AR tests also supported the overall validity of the model by providing evidence for a significant negative AR(1) and a non-significant AR(2).

Finally, we replicated our GMM-SYS estimates using the less informative specification (see the discussion in Sect. 5) with the skilled to unskilled ratio as dependent variable (see Table 9 in the Appendix). As can be seen, our results about the skill-biased role of both the foreign ownership and the proximity to the capital city are strongly confirmed by this auxiliary estimation.

\section{Concluding remarks}

This paper has conducted empirical investigations to establish the role played by globalization and technology transfer in determining employment evolution in the manufacturing sector of Ethiopia. To this end, the paper has studied the extent to which the level of overall manufacturing employment was determined by trade, FDI and technology; and if globalization and technology transfer played a role in instigating SBTC. The empirical analysis relied on manufacturing survey data for the period 1996-2004 and deployed alternative econometric estimators.

The findings in the paper lead to two main conclusions concerning the characteristics of manufacturing sector employment in Ethiopia. The first main conclusion pertains to the quantitative effect of globalization on total manufacturing employment at the firm-level. Specifically, trade and foreign ownership are found to 
have a labour-augmenting effect. Therefore, no negative employment effects of globalization are obvious in the Ethiopian manufacturing sector. The investigation to determine whether the manufacturing sector exhibits the presence of skill-bias lends some evidence to this effect. In particular, foreign ownership and proximity to the capital city are found to lead to a higher demand for skilled workers, as opposed to unskilled ones. The foreign ownership related finding thus suggests two things: first, the increase in total firm-level employment associated with foreign ownership stems mostly from the effect of foreign ownership on the demand for skilled labour; secondly, it lends some support to FDI-linked channels of a SBT transfer being in operation. The significant effect associated with being located in and around the capital city may suggest the presence of positive agglomeration effects. It may also be an indicator of the fact that the capital city and its hinterlands represent better synergies of infrastructure and technology.

In contrast, involvement in exporting activity is found to lead to higher demand for unskilled workers. This suggests that the effect of exporting activity on total firm-level employment is largely the result of its effect on unskilled labour. This finding is in contrast with the expectation of a possible skill bias involved by a process of "learning by exporting". However, at least for the time period considered in this study, it may well be that the Ethiopian manufacturing was still characterized by a dominant role of an HOSS effect, with exporting still stemming from traditional and low-skill intensive manufacturing activities.

The finding that FDI is the main channel through which skilled labour is demanded in the Ethiopian manufacturing may be of some relevance for policy. The current extensive public sector investment in infrastructural projects may be commendable in this respect, since availability of adequate infrastructure may be the missing element needed to attract FDI. On the other hand, the fact that the economy is still dominated by a State sector that is undertaking extensive investment activities may pose the risk of crowding-out relatively more technologically advanced FDI. Finally, it is needless to state that a favourable investment climate that accords the private sector with the requisite credit and financial infrastructure, among others, is vital in attracting FDI and the development of the manufacturing sector. Equally, globalization and technology transfer necessitate an educated and skilled labour force. A skill-shortage would not only undermine both technological upgrading and manufacturing employment, but it also risks thwarting the flow of FDI. There is thus a need to also devote particular attention to education and training policies in Ethiopia.

Open Access This article is distributed under the terms of the Creative Commons Attribution 4.0 International License (http://creativecommons.org/licenses/by/4.0/), which permits unrestricted use, distribution, and reproduction in any medium, provided you give appropriate credit to the original author(s) and the source, provide a link to the Creative Commons license, and indicate if changes were made.

\section{Appendix}

Tables 8 and 9. 
Table 8 The distribution of enterprises in the estimation sample

\begin{tabular}{lc}
\hline Year & No. of establishments \\
\hline 1996 & 298 \\
1997 & 394 \\
1998 & 440 \\
1999 & 462 \\
2000 & 465 \\
2001 & 478 \\
2002 & 572 \\
2003 & 639 \\
2004 & 504 \\
N & 4252 \\
\hline
\end{tabular}

Table 9 Regression results using OLS, FE and system-GMM for the ratio of skilled to unskilled workers

\begin{tabular}{|c|c|c|c|}
\hline $\begin{array}{l}\text { Dependent variable: } \\
\text { skilled/unskilled }\end{array}$ & OLS & $\mathrm{FE}$ & SYS-GMM \\
\hline $\begin{array}{l}\text { Lagged employment } \\
\text { ratio }\end{array}$ & $\begin{array}{l}0.510 * * * \\
(0.0759)\end{array}$ & $\begin{array}{l}0.0833 * * * \\
(0.02390\end{array}$ & $\begin{array}{l}0.293 * * * \\
(0.0674)\end{array}$ \\
\hline Total wage ratio & $\begin{array}{l}-0.0784 * * * \\
(0.0140)\end{array}$ & $\begin{array}{l}-0.0609 * * * \\
(0.016)\end{array}$ & $\begin{array}{l}-0.103 * \\
(0.0601)\end{array}$ \\
\hline Real output & $\begin{array}{l}0.00337 \\
(0.0180)\end{array}$ & $\begin{array}{l}0.0107 \\
(0.0354)\end{array}$ & $\begin{array}{l}0.170^{*} \\
(0.0926)\end{array}$ \\
\hline Investment/output ratio & $\begin{array}{l}0.0203 * * * \\
(0.0056)\end{array}$ & $\begin{array}{l}0.00494 \\
(0.0228)\end{array}$ & $\begin{array}{l}0.000454 \\
(0.0686)\end{array}$ \\
\hline Location dummy & $\begin{array}{l}0.163 * * * \\
(0.0472)\end{array}$ & $\begin{array}{l}0.252 \\
(0.250)\end{array}$ & $\begin{array}{l}0.200 * * * \\
(0.0663)\end{array}$ \\
\hline $\begin{array}{l}\text { Foreign ownership } \\
\text { share }\end{array}$ & $\begin{array}{l}0.148 \\
(0.0979)\end{array}$ & $\begin{array}{l}0.163 \\
(0.172)\end{array}$ & $\begin{array}{l}2.039 * * \\
(0.937)\end{array}$ \\
\hline Export/output ratio & $\begin{array}{l}0.111 \\
(0.1060)\end{array}$ & $\begin{array}{l}-0.077 \\
(0.544)\end{array}$ & $\begin{array}{l}-0.497 \\
(0.624)\end{array}$ \\
\hline Constant & $\begin{array}{l}0.578 * * \\
(0.2360)\end{array}$ & $\begin{array}{l}0.572 \\
(0.521)\end{array}$ & $\begin{array}{l}-1.424 \\
(1.278)\end{array}$ \\
\hline Time dummies & Yes & Yes & Yes \\
\hline Sector dummies & Yes & No & Yes \\
\hline Observations & 2863 & 2863 & 2863 \\
\hline Number of firms & & & 881 \\
\hline R-squared & 0.295 & 0.019 & \\
\hline $\operatorname{AR}(1)$ & & & $\begin{array}{l}-2.846^{* * *} \\
(0.004)\end{array}$ \\
\hline $\operatorname{AR}(2)$ & & & $\begin{array}{l}0.944 \\
(0.345)\end{array}$ \\
\hline
\end{tabular}


Table 9 continued

\begin{tabular}{lcc}
\hline $\begin{array}{l}\text { Dependent variable: } \\
\text { skilled/unskilled }\end{array}$ & OLS & SYS-GMM \\
\hline Wald test & $190.9^{* * * *}$ \\
& $(0.000)$ \\
Hansen & 153.8 \\
Number of instruments & $(0.184)$ \\
\hline
\end{tabular}

Robust standard errors (for coefficients) and $p$ values (for tests) in brackets $* * *, * *$, and $*$ indicate the statistical significance at the 1,5 , and $10 \%$, respectively

\section{References}

Acemoglu, D. (2003). Patterns of skill premia. Review of economic studies, 70, 199-230.

Aguirregabiria, V., \& Alonso-Borrego, C. (2001). Occupational structure, technological innovation, and reorganization of production. Labour Economics, 8, 43-73.

Almeida, R. (2009). Openness and technological innovation in East Asia: have they increased the demand for skills? (Discussion Paper No 4474). Bonn: Institute for the Study of Labor (IZA).

Anderson, T. W., \& Hsiao, C. (1982). Formulation and estimation of dynamic models using panel data. Journal of Econometrics, 18, 47-82.

Araújo, B. C., Bogliacino, F., \& Vivarelli, M. (2011). Technology, trade and skills in Brazil: some evidence from microdata. CEPAL Review, 105, 157-171.

Arellano, M., \& Bond, S. (1991). Some tests of specification for panel data: monte Carlo evidence and an application to employment equations. Review of Economic Studies, 58, 277-297.

Autor, D., Katz, L., \& Krueger, A. (1998). Computing inequality: have computers changed the labor market? Quarterly Journal of Economics, 113, 1169-1214.

Barba Navaretti, G., Solaga, I., \& Takacs, W. (1998). When vintage technology makes sense: matching imports to skills. Labour, 12, 353-362.

Berman, E., Bound, J., \& Griliches, Z. (1994). Changes in the demand for skilled labor within U.S. manufacturing industries. Quarterly Journal of Economics, 109, 367-398.

Berman, E., \& Machin, S. (2000). Skill-Biased technology transfer around the world. Oxford Review of Economic Policy, 16, 12-22.

Berman, E., \& Machin, S. (2004). Globalization, skill-biased technological change and labor demand. In E. Lee \& M. Vivarelli (Eds.), Understanding globalization, employment and poverty reduction (pp. 39-66). New York: Palgrave Macmillan.

Bigsten, A., Collier, P., Dercon, S., Fafchamps, M., Gauthier, B., Gunning, W. J., \& Zeuf, A. (2004). Do African manufacturing firms learn from exporting? Journal of Development Studies, 40, 115-141.

Bigsten, A., \& Gebreeyesus, M. (2007). The small, the young and the productive: determinants of manufacturing firm growth. Ethiopia. Economic Development and Cultural Heritage (University of Chicago Press), 55, 813-840.

Bigsten, A., Gebreeyesus, M., \& Soderbom, M. (2009). Gradual trade liberalization and firm performance in Ethiopia. Journal of Development Studies, 45, 1594-1614.

Blundell, R., \& Bond, S. (1998). Initial conditions and moment restrictions in dynamic panel data models. Journal of Econometrics, 87, 115-143.

Bond, S., Hoeffler, A., \& Temple, J. (2001). GMM estimation of empirical growth models (Discussion Paper No. 3048). London: Centre for Economic Policy Research.

Caroli, E., \& Van Reenen, J. (2001). Skill-biased organizational change? evidence from a panel of British and French establishments. Quarterly Journal of Economics, 116, 1449-1492.

Coe, D. T., \& Helpman, E. (1995). International R\&D spillovers. European Economic Review, 39, 859-887.

Coe, D. T., Helpman, E., \& Homaister, A. (1997). North-South spillovers. Economic Journal, 107, $134-149$. 
Conte, A., \& Vivarelli, M. (2011). Globalization and employment: imported skill biased technological change in developing countries. Developing Economies, 49, 36-65.

Dunning, J. H., \& Fontanier, F. (2007). Multinational enterprises and the new development paradigm: consequences for host country development. Multinational Business Review, 15, 25-45.

Epifani, P. (2003). Trade liberalization, firm performances and labor market outcomes in the developing world, what can we learn from micro-level data? Rivista italiana degli economisti (Società editrice il Mulino), 3, 455-486.

Fajnzylber, P., \& Fernandes, A. (2009). International economic activities and skilled demand: evidence from Brazil and China. Applied Economics, 41, 563-577.

Feenstra, R. C., \& Hanson, G. H. (1997). Foreign direct investment and relative wages: evidence from Mexico's maquiladoras. Journal of International Economics, 42, 371-393.

Gkypali, A., Rafailidis, A., \& Tsekouras, K. (2015). Innovation and export performance: do young and mature innovative firms differ? Eurasian Business Review, 5, 397-415.

Görg, H., \& Strobl, E. (2002). Relative wages, openness and skill-biased technological change (Discussion Papers No. 596) Bonn: Institute for the Study of Labor (IZA).

Griliches, Z. (1969). Capital-skill complementarity. Review of Economics and Statistics, 51, 465-468.

Halaby, N. C. (2004). Panel models in sociological research: theory into practice. Annual Review of Sociology, 30, 507-544.

Hanson, G., \& Harrison, A. (1999). Trade and wage inequality in Mexico. Industrial and Labor Relations Review, 52, 271-288.

Hsiao, C. (1986). Analysis of panel data. Cambridge: Cambridge University Press.

IMF (2013) The Federal Democratic Republic of Ethiopia (IMF Country Report No. 13/308). Washington: Author.

Katz, L., \& Autor, D. H. (1999). Changes in the wage structure and earnings of inequality. In O. Ashenfelter \& D. Card (Eds.), Handbook of Labor Economics (Vol. 3). Amsterdam: Elsevier.

Keller, W. (2001). International technology diffusion (Working Paper No. 8573). Cambridge, Massachusetts: National Bureau of Economic Research.

Keller, W. (2004). International technology diffusion. Journal of Economic Literature, 42, 752-782.

Lachenmaier, S., \& Rottmann, H. (2011). Effects of innovation on employment: a dynamic panel analysis. International Journal of Industrial Organization, 29, 210-220.

Lee, E., \& Vivarelli, M. (2004). Understanding Globalization, Employment and Poverty Reduction (Eds). New York: Palgrave Macmillan.

Lee, E., \& Vivarelli, M. (2006a). Globalization, Employment, and Income Distribution in Developing Countries(Eds). New York: Palgrave Macmillan.

Lee, E., \& Vivarelli, M. (2006b). The Social Impact of Globalization in Developing Countries. International Labor Review, 145, 167-184.

Machin, S., \& Van Reenen, J. (1998). Technology and changes in skill structure: evidence from seven OECD countries. Quarterly Journal of Economics, 113, 1215-1244.

Mayer, J. (2000). Globalization, technology transfer and skill accumulation in low-income countries. Globalization and the obstacles to the successful integration of small vulnerable economies. Geneva: UNCTAD.

Melitz, M. (2003). The impact of trade on aggregate industry productivity and intra-industry reallocations. Econometrica, 71, 1695-1725.

Meschi, E., Taymaz, E., \& Vivarelli, M. (2011). Trade, technology and skills: evidence from Turkish microdata. Labour Economics, 18, S60-S70.

Meschi, E., \& Vivarelli, M. (2009). Trade and income inequality in developing countries. World Development, 37, 287-302.

Mitra, A., \& Jha, A. K. (2015). Innovation and employment: a firm level study of Indian industries. Eurasian Business Review, 5, 45-71.

Perkins, R., \& Neumayer, E. (2005). International technological diffusion, latecomer advantage and economic globalization: a multi-technology analysis. Annals of the American Association of Geographers, 95, 789-808.

Piva, M. (2003). The Impact of Technology Transfer on Employment and Income Distribution in Developing Countries: A Survey of Theoretical Models and Empirical Studies (Working Paper No. 15). Geneva: International Policy Group, Policy Integration Department of the ILO.

Piva, M., Santarelli, E., \& Vivarelli, M. (2005). The skill bias effect of technological and organisational change: evidence and policy implications. Research Policy, 34, 141-157. 
Robbins, D. (1996). HOS hits facts: facts win; evidence on trade and wages in the developing World (Working Paper No. 119). Paris: OECD Development Centre.

Robbins, D. (2003). The impact of trade liberalization upon inequality in developing countries-A review of theory and evidence (Working Paper No. 13). Geneva: ILO.

Robbins, D., \& Gindling, T. H. (1999). Trade liberalization and the relative wages for more-skilled workers in Costa Rica. Review of Development Economics, 3, 140-154.

Schiff, M., \& Wang, Y. (2006). On the quantity and quality of knowledge: The impact of openness and foreign R\&D on North-North and North-South technology spillovers. In B. Hoeckman \& B. S. Javoricik (Eds.), Global integration and technology transfer (pp. 99-112). New York: Palgrave Macmillan.

Shiferaw, A. (2005). Firm heterogeneity and market selection in Sub-Saharan Africa: does it spur industrial progress? (Working Papers - General Series 1765019171). The Hague: International Institute of Social Studies of Erasmus University.

Taylor, L. (2004). External liberalization in Asia, post-socialist Europe and Brazil. In E. Lee \& M. Vivarelli (Eds.), Understanding globalization, employment and poverty reduction (pp. 13-34). New York: Palgrave Macmillan.

UNCTAD (2004). An investment guide to Ethiopia: opportunities and conditions. Geneva: Author.

UNCTAD (2007). The Least Developed Countries (2007 Report). Geneva: Author.

Van Reenen, J. (1997). Employment and technological innovation: evidence from U.K. manufacturing firms. Journal of Labor Economics, 15, 255-284.

Verhoogen, E. A. (2008). Trade, quality upgrading, and wage inequality in the Mexican manufacturing sector. The Quarterly Journal of Economics, 123, 489-530.

Vivarelli, M. (2014). Innovation, employment and skills in advance and developing countries: a survey of economic literature. Journal of Economic Issues, 48, 123-154.

Welch, F. (1970). Education in production. Journal of Political Economy, 78, 35-59.

World Bank (2013a). Ethiopia public sector reform approach: Building the developmental state-A review and assessment of the Ethiopian approach to public sector reform (World Bank, Report No: ACS3695). Washington: Author.

World Bank (2013b). Africa's Pulse: An analysis of issues shaping Africa's economic future (World Bank, the Office of the Chief Economist Report, vol.8). Washington DC, Author.

Yeaple, S. R. (2005). A simple model of firm heterogeneity, international trade and wages. Journal of International Economics, 65, 1-20. 